\title{
Transparency and government trust
}

FRANCISCO JOSÉ BASTIDA ALBALADEJO, Ph.D.

Conference keynote*

https://doi.org/10.3326/pse.43.1.3

\footnotetext{
* Received: January 13, 2019

Accepted: January 15, 2019
}

\begin{abstract}
A keynote speech given at the conference "Public Sector Economics 2018 - Fiscal openness: transparency, participation and accountability in fiscal policies" organized by the Institute of Public Finance, International Budget Partnership and Friedrich-Ebert-Stiftung in Zagreb on October 26, 2018.
\end{abstract}

Francisco José BASTIDA ALBALADEJO

University of Murcia, Facultad Economía y Empresa, Campus de Espinardo, E-30100, Spain

American University of Armenia, 40 Marshal Baghramyan Avenue, Yerevan 0019, Republic of Armenia

e-mail: alba@um.es

ORCiD: 0000-0001-9875-3817 


\section{INTRODUCTION}

Trust is essential for democracies, for it enhances the legitimacy of governments by linking citizens, their institutions and politicians (Godefroidt, Langer and Meuleman, 2017). Besides, trust is considered a solution to many current social problems, including the lack of confidence stemming from the crisis in democratic governance (Choi and Woo, 2016).

An appropriate level of confidence in institutions is essential for democratic governance (Yang and Holzer, 2006). In addition, public trust in the government is not only important for citizens, but also for public officials, since it is essential that they receive the necessary support for implementation of public policies (Gordon, 2000).

\section{EVOLUTION OF GOVERNMENT TRUST}

Although trust is considered one of the critical components of good governance (Wu, Ma and Yu, 2017), public trust in governments has decreased significantly in recent decades (Gordon, 2000; Park et al., 2015; Welch, Hinnant and Moon, 2005). According to Bouckaert and van de Walle (2003), on the one hand, politicians, journalists and citizens show concern about the decrease in confidence in the government. On the other, this lack of confidence lessens the legitimacy of governments and makes it complicated for citizens to agree with public policies, which becomes a major problem when these policies mean unpopular measures in times of crisis. This concern has to do with the diminution of social and political trust, the confidence of citizens in their political leaders, in governmental institutions and beliefs in democratic norms and values (Choi and Woo, 2016).

\section{TRANSPARENCY AND TRUST}

The literature shows that transparency increases the degree of trust (Park and Blenkinsopp, 2011). Transparency is the most powerful solution, the cornerstone of one of the most intangible problems of democratic governance: the increasing distrust of citizens towards the government.

Zhao and $\mathrm{Hu}$ (2017) define transparency as a strategic responsibility, essential to enhance trust in relationships (Wasike, 2016; Song and Lee, 2016; Bauhr and Grimes, 2014). In addition, transparency creates a climate of trust among people and encourages them to believe more in governments, fostering an environment of openness that allows citizens to control institutions and participate in decisionmaking. Thus, trust is essential in the ability to implement, for example, participative budgets, in which taxpayers may decide the way their resources are used to increase the general welfare.

For some academics, political distrust is not a consequence of weak government, but rather, it is the matter of a better-informed public trusting government more (Cook, Jacobs and Kim, 2010), since citizens will understand more clearly how local government policies contribute to public welfare (Porumbescu, 2015). 
Accordingly, disseminating information about government activities is crucial to increasing public confidence. As will be indicated later, this information must be the leverage that makes people hold their incumbents accountable. This transparency must have a real impact on how citizens assess their politicians' performance, so that democracy is strengthened.

Beyond these effects of transparency on trust, some authors such as Buehn, Dell'Anno and Schneider (2017), consider that the lack of transparency impacts on the loss of confidence, which in turn triggers fiscal illusion. Fiscal illusion is connected with transparency through the agency theory, which posits that politicians (agents) may not always work to increase citizens' (principals') welfare, but sometimes the former may seek to achieve their own targets, regardless of citizens' needs. Thus, the agency theory shows that higher levels of information reduce information asymmetries, which in turn limits potential conflicts of interest between principals and agents and increases confidence in politicians.

\section{EFFECTIVE TRANSPARENCY AS THE KEY FOR GOVERNMENT TRUST}

According to all the arguments stated earlier in this short note, it is not how many technical documents are made available to citizens, but how the data are conveyed so that people get the key, relevant information (it is about "quality" rather than "quantity" of transparency). Accordingly, transparency, to be effective, should meet three basic requirements:

- Transparency should report relevant information, and not contribute to data overload with documents that are too technical.

- Transparency should be based on unbiased, fair information.

- Data should be objective and comparable with counterparts.

Finally, if we address only the transparency issue, we will inevitably be fixing only the "supply" side of the system. Citizens, the "demand" side, should be trained to hold their politicians accountable in accordance with the transparent data disclosed. Otherwise, transparency is to no avail. If they trigger no citizen or taxpayer response, the huge amounts of data remain sterile, with nobody understanding or making practical use of the information released. 


\section{REFERENCES}

1. Bauhr, M. and Grimes, M., 2014. Indignation or Resignation: The Implications of Transparency for Societal Accountability. Governance, 27(2), pp. 291-320. https://doi.org/10.1111/gove.12033

2. Bouckaert, G. and van de Walle, S., 2003. Comparing Measures of Citizen Trust and User Satisfaction as Indicators of 'Good Governance': Difficulties in Linking Trust and Satisfaction Indicators. International Review of Administrative Sciences, 69(3), pp. 329-343. https://doi.org/10.1177/00208523030693003

3. Buehn, A., Dell'Anno, R. and Schneider, F., 2017. Exploring the dark side of tax policy: an analysis of the interactions between fiscal illusion and the shadow economy. Empirical Economics, 54(4), pp. 1609-1630. https://doi. org/10.1007/s00181-017-1277-7

4. Choi, E. and Woo, J., 2016. The Origins of Political Trust in East Asian Democracies: Psychological, Cultural, and Institutional Arguments. Japanese Journal of Political Science, 17(3), pp. 410-426. https://doi.org/10.1017/ S1468109916000165

5. Cook, F. L., Jacobs, L. R. and Kim, D., 2010. Trusting What You Know: Information, Knowledge, and Confidence in Social Security. The Journal of Politics, 72(2), pp. 397-412. https://doi.org/10.1017/S0022381610000034

6. Godefroidt, A., Langer, A. and Meuleman, B., 2017. Developing political trust in a developing country: the impact of institutional and cultural factors on political trust in Ghana. Democratization, 24(6), pp. 906-928. https://doi.org/ 10.1080/13510347.2016.1248416

7. Gordon, M. T., 2000. Public Trust in Government: The US Media as an Agent of Accountability? International Review of Administrative Sciences, 66(2), pp. 297-310. https://doi.org/10.1177/0020852300662006

8. Park, H. and Blenkinsopp, J., 2011. The roles of transparency and trust in the relationship between corruption and citizen satisfaction. International Review of Administrative Sciences, 77(2), pp. 254-274. https://doi.org/10.1177/ 0020852311399230

9. Park, M. J. [et al.], 2015. Trust in government's social media service and citizen's patronage behavior. Telematics and Informatics, 32(4), pp. 629-641. https://doi.org/10.1016/j.tele.2015.02.006

10. Porumbescu, G. A., 2015. Using Transparency to Enhance Responsiveness and Trust in Local Government. State and Local Government Review, 47(3), pp. 205-213. https://doi.org/10.1177/0160323X15599427

11. Song, C. and Lee, J., 2016. Citizens' Use of Social Media in Government, Perceived Transparency, and Trust in Government. Public Performance \& Management Review, 39(2), pp. 430-453. https://doi.org/10.1080/15309576.2 015.1108798

12. Wasike, B., 2016. FoIA in the age of "Open. Gov": An analysis of the performance of the Freedom of Information Act under the Obama and Bush administrations. Government Information Quarterly, 33(3), pp. 417-426. https://doi. org/10.1016/j.giq.2016.05.001 
13. Welch, E. W., Hinnant, C. C. and Moon, J. M., 2005. Linking Citizen Satisfaction with E-Government and Trust in Government. Journal of Public Administration Research and Theory, 15(3), pp. 371-391. https://doi.org/10.1093/ jopart/mui021

14. Wu, W., Ma, L. and Yu, W., 2017. Government transparency and perceived social equity: Assessing the moderating effect of citizen trust in China. Administration \& Society, 49(6), pp. 882-906. https://doi.org/10.1177/ 0095399716685799

15. Yang, K. and Holzer, M., 2006. The Performance-Trust Link: Implications for Performance Measurement. Public Administration Review, 66(1), pp. 114-126. https://doi.org/10.1111/j.1540-6210.2006.00560.x

16. Zhao, D. and Hu, W., 2017. Determinants of public trust in government: empirical evidence from urban China. International Review of Administrative Sciences, 83(2), pp. 358-377. https://doi.org/10.1177/0020852315582136. 